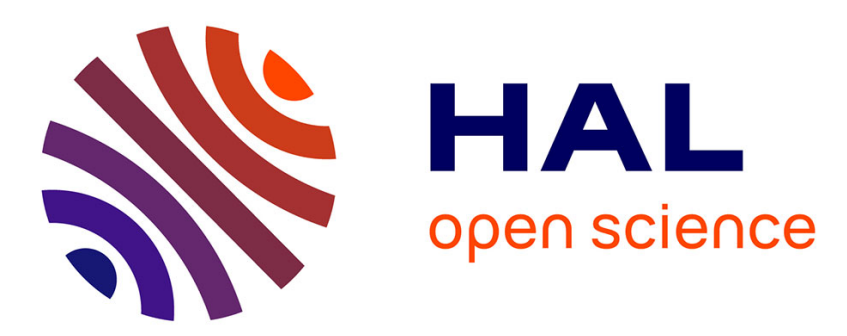

\title{
Method of Innovation Assessment of Products and Processes in the Initial Design Phase
}

\author{
Bartosz Pryda, Marek Mysior, Sebastian Koziolek
}

\section{To cite this version:}

Bartosz Pryda, Marek Mysior, Sebastian Koziolek. Method of Innovation Assessment of Products and Processes in the Initial Design Phase. 18th TRIZ Future Conference (TFC), Oct 2018, Strasbourg, France. pp.75-83, 10.1007/978-3-030-02456-7_7 . hal-02279769

\section{HAL Id: hal-02279769 \\ https://hal.inria.fr/hal-02279769}

Submitted on 5 Sep 2019

HAL is a multi-disciplinary open access archive for the deposit and dissemination of scientific research documents, whether they are published or not. The documents may come from teaching and research institutions in France or abroad, or from public or private research centers.
L'archive ouverte pluridisciplinaire HAL, est destinée au dépôt et à la diffusion de documents scientifiques de niveau recherche, publiés ou non, émanant des établissements d'enseignement et de recherche français ou étrangers, des laboratoires publics ou privés. 


\title{
Method of innovation assessment of products and processes in the initial design phase
}

\author{
Bartosz Pryda $^{1}$, Marek Mysior ${ }^{*}$, Sebastian Koziołek ${ }^{1}$ \\ Wroclaw University of Science and Technology, Department of Machine Design \& Research, \\ Lukasiewicza 7/9, 50-371 Wroclaw, Poland \\ * Corresponding author.E-mail address: marek.mysior@pwr.edu.pl
}

\begin{abstract}
A key for economic success of an enterprise is proper decision making regarding product and process planning. The aim of this study was to develop a method of innovation assessment of products and processes that will be applicable at early stage of design and throughout life cycle of a product. The effectiveness of proposed method was examined on real-life case studies. The method is based on systematic, quantitative analysis of parameters, unlike current approaches that concentrate rather on subjective opinions or assessment of the design process, not the design itself. Proposed method comprises some already known tools regarding functional modelling including TRIZ and adopts them to innovation assessment environment. Innovation assessment using proposed method allows to facilitate decision making process regarding choice of concept to be further developed at an early stage of a design process, reducing cost and time of development of new products and processes.
\end{abstract}

\section{Introduction}

One of the conditions for maintaining global, economic growth is systematic, innovative and conceptual design of new products. It should be remembered that every invention ceases to be an innovation over time. Maintaining a high level of system usefulness in the long-term is associated with maintaining its stable level of ideality [1]. Furthermore in TRIZ, ideality is the factor that determines the development of technical systems. According to [2], ideality is defined as the ratio of benefits to costs and harms. It means that the bigger the benefit, the bigger the ideality of the system providing minimal costs and harms. Because of this, technical systems that can be described in terms of the ideality can be compared and thus assessed even at an early stage of the design process. In the system used, the proportion of useful to useless functions is changeable. This is due to a change in the need for the operation of this system and a partial change in its design 
assumptions. In practice, this is visible by the constant adaptation of elements of a given technical object to new design assumptions. When this adaptation ceases to be possible or is too expensive, new technology is implemented. Furthermore, according to one of the TRIZ trends of evolution [2], [3] ideality increases in time, which does not necessarily mean that the technical system will achieve market success. There are many examples of technical systems having high level of ideality and not being implemented to the market. In this article authors present a new method of innovation assessment of products and processes that take into account the ideality as specified in TRIZ, but also takes into account several other factors that are important in terms of commercialization.

\section{Problem description}

Innovation assessment of product and services is connected with the possibility of the product to be successfully introduced to the market. There are many methods on how to measure innovation in conceptual design among which some of them concentrate on the assessment of the system functions [1], [4]-[6] and some on the economic aspects of innovation [7]-[10]. From the point of view of an ideality of technical systems, the better the system the more useful functions it has providing minimal harm. It can be described by the equation [1]:

Where:

I - system ideality

$F_{u}$ - useful function

$\mathrm{F}_{\mathrm{b}}$ - useless function

Taking into consideration only ideality of the system it can be observed that through elimination of harmful functions and addition of useful functions by application of 40 inventive principles of TRIZ [2], functional analysis and trimming [11] and other TRIZ tools continuous development of products is achieved. Nevertheless, manipulation of functions of the technical system is not directly related to the economic result of commercialization, that is why authors have deepen the analysis to include financial factors in innovation assessment by modifying eq. 1 .

According to [12], useful function presented in eq. 1. can be divided into three factors presented by [13], what makes a direct link between the parameters of technical system and market response. 
According to the equation (2), useful function can be described as a sum of three separate set of functions. The first one is associated with attractive functions, which describe novel, unexpected features technical system delivers that are directly related to development trends and customer needs. The second one, called "linear-quality functions" is connected with performance of technical system- the better the system performs, the bigger usefulness is provided. The last set of useful functions is called "must-be requirements" and represents all features of the system that are necessary and vital for a technical system for the customer to be satisfied with the product. Relation of attributes assigned to each category with customers' satisfaction is presented on fig. 1 .

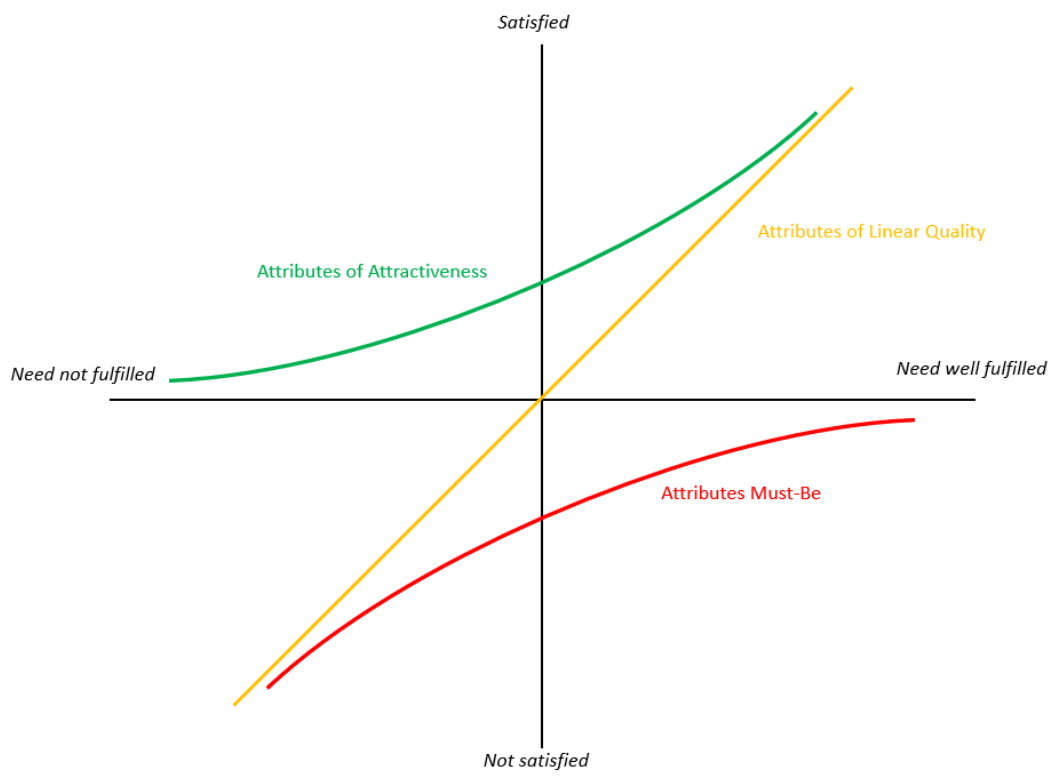

Figure 1. Relation between fulfillment of needs and customers' satisfaction according to the KANO model [13]

As shown in [12], proportion of attractiveness, linear quality and must-be attributes in technical system is changing in time and thus the innovativeness of technical system.

\section{New innovativeness metrics}

According to [2], ideality can be increased either by introducing new useful functions to the system or by reduction of expenses and harms through elimination of harmful functions. It was observed however, that even if the ideality of the 
system grows through reduction of costs, it is not enough for the system to remain innovative and commercially attractive to customers. It means, that maintaining the same level of ideality of the system is not enough for the product to remain on the market. Based on fig. 2 from [12] one may conclude, that a particular function (taking pictures by mobile phone for example) is changing in time from an attractive function, through linear-quality function to the must-be function. Comparing this with profit the system delivers, it decreases in time even though costs of manufacturing are decreasing. Taking into account eq (2) one may conclude, that the value of Fu does not change (the sum is constant, not even one function is neither removed nor added to the system). Providing constant costs of manufacturing, the ideality of the system remains stable and yet profits are decreasing. This means, that attractive, linear quality and must be attributes influence innovativeness in a different way. The proposed innovativeness metrics is presented in eq. (3)

where profits are represented by the KANO model and harmful functions are represented as a sum of all expenses in the system (material costs, labor costs and overheads). Those costs can be evaluated at early design phase using for example Computer Aided Engineering techniques. The numerator of equation (3) is obtained by determination of fields of attributes, as described further in the presented work. This method is a comparative method in which design concept at an early stage is being compared to the other design concept providing costs and functions of the systems are known.

In order to obtain values of $\mathrm{Fu}_{\mathrm{A}}, \mathrm{Fu}_{\mathrm{LQ}}$ and $\mathrm{Fu}$ MB, authors propose adaptation of fig. 1 that will relate the novelty of the analyzed function with its quality, as shown on fig. 2. In order to obtain the novelty of the technical system, it is necessary to extract all useful functions using known tools like functional analysis in TRIZ [2] or other methods [14] and associate them with specific attributes (A,LQ or MB). This association is being made heuristically according to the rules below: 


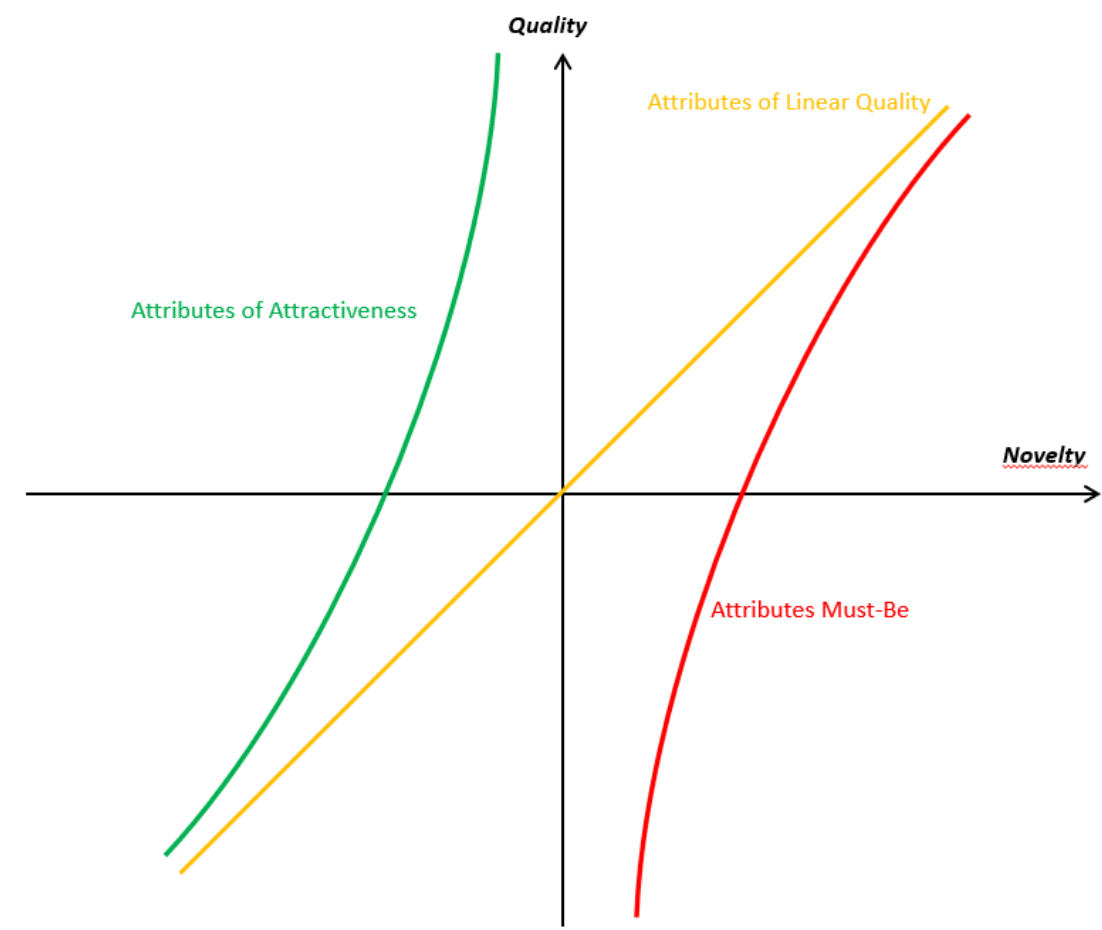

Figure 2. Graph for obtaining fields of attributed that are used in innovativeness metrics

A - the attribute of a new design solution that so far has not been applied for purposes similar to the one implemented in the system under study. Often this attribute represents the introduction of new functions within the system,

Lq - a linear quality attribute, it includes design solutions that have been developed and applied earlier than in the examined system, however with an increased or reduced efficiency compared to previously known solutions design,

M - attribute of basic requirements, it includes such design solutions, which have been developed and applied earlier than in the examined system and defines the compliance only with the basic expectations of users,

Fb - the attribute of a useless function, it includes design solutions that in no way affect the operation of the system relative to the considered innovation assessment criterion.

For each function presented, it is necessary to evaluate quality of the function by comparing numerical parameters that describe the outcome of a particular function. For example, one of a possible useful function of a car is to give 
possibility to drive long distance. Outcome of this function can be described using such parameter as distance travelled $[\mathrm{km}]$, which is a numerical attribute. Scaling of the axis can be done by normalization methods in which the minimum value on axis "quality" is 0 and the maximum is 1 . Placing those values on vertical axis of fig. (2) and placing them on appropriate attribute (LQ, A, MB) gives novelty value (also normalized from -1 to 1) that is included in evaluation of the innovativeness metrics according to the eq. 3 .

\section{Innovation assessment of thermal insulation systems.}

In this example, shortened innovation assessment method is presented based on the thermal insulation systems example. Numerical results of evaluation are not presented in this case study, because what is important is the method itself and not the result.

At the beginning of innovation assessment process, it is necessary to extract all useful functions related to the technical system being analyzed. For example, in the case of thermal insulation systems, those functions are:

I. Insulating buildings

Ensuring durability of outer building structure

Decorating

With each function being analyzed, there is set of requirements that have to be fulfilled in order to realize the function, such as:

(]) Thermal insulation ability

Installation (easiness of installation)

Environmental protection

Resistance to fire

Resistance to external factors

Resistance to water and moisture

(1) Attractiveness

Each of these conditions should be now marked by subordinate numbers. The technical requirements of the process, such as, for example, thermal insulation ability (condition 1.1) can be met by applying a low by using insulating materials (method 1.1.1). Next, the parameters of the insulating materials are identified as parameters responsible for meeting the condition of the superior process. Fig. 3. Presents all functions in red, requirements in green, methods in blue and parameters in white together with their numbers for clarification. Each of the applied methods receives innovation attributes assigned to the parameters responsible for meeting the superior condition(A, LQ, MB). For example, using thermal insulating materials method receives the innovation attributes assigned to the parameters: 1.1.11., 1.1.1.2, 1.1.1.3, ... These parameters are responsible for the fulfillment of the superior function, which is thermal insulation. 


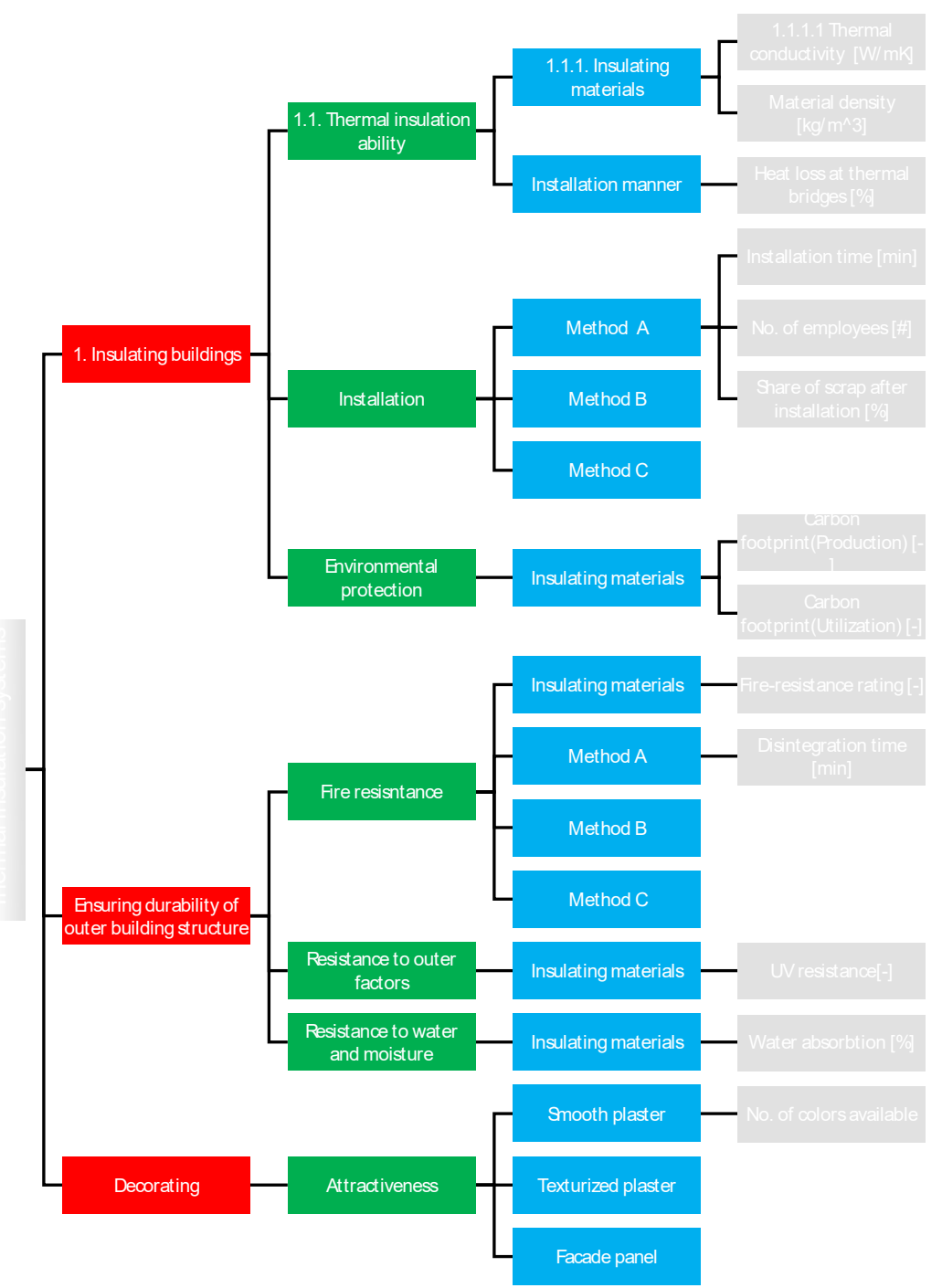

Figure 3. Model of extraction of quality attributes in which useful functions are shown in red, requirements for the particular function are in green, technical methods of requirement fulfillment are in blue and the quality parameters are in white

The basic element of measuring the level of system innovation is assignment of proper attributes to methods and parameters responsible for superior conditions of the system. Attributes of innovation are the features of the system's functions assigned to methods operation of the system and its parameters according to the innovation assessment criteria. 
As a result, the level of system innovation is determined on the basis of system parameters that are scaled according to the characteristics of the attribute they received. Based on the scaled process parameters, the initial level of innovation is pre-identified. Then it is known whether the system parameters in the attribute characteristics are given a positive or negative quality value. In addition, the presented model identifies extreme levels of system parameters' quality marked with points on the relevant characteristics of the innovation attribute (Figure 8). Next, the points of the extreme values of the process parameters represented by the unit of quality on the attribute curves should be combined. As a result, the indicated areas of quadrilateral surfaces (Figure 8) determine the level of system innovation. The surface area P1 (green) is the scope of effective innovation and/or highly optimized known technology. The P2 (blue) area represents the scope of application of these design solutions that have elements of innovation. However, these solutions are not very effective and do not improve the users' satisfaction. Nevertheless, the P2 field is extremely important in studying the level of innovation because it sets the direction of product development. Field P3 (yellow) defines the scope of applied design solutions in the system, which are only the basic requirements of users. This area of evaluation indicates the lack of innovation, but also the high level of meeting the basic user requirements. The P4 field (red) indicates the use of risky design solutions. These solutions do not meet the basic user requirements or are extremely inefficient.

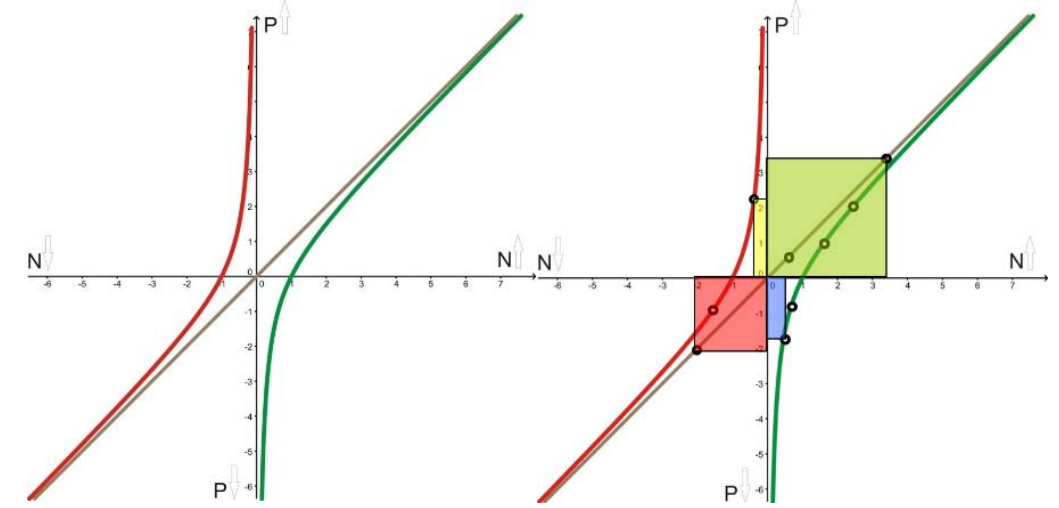

Figure 4. Model of determining the level of system innovation. Fields: P1 (green), P2 (blue), P3 (yellow), P4 (red).

At the end of the assessment process, values of obtained fields are summed together in specific categories and when costs are added to eq (3), level of innovativeness is obtained.

\section{Conclusions}


The presented Innovation assessment method finds its application in the design of interdisciplinary systems and their evaluation at an early stage of the design process as soon as the costs can be estimated. Due to its versatility it is possible to apply this method across various areas. The tools implemented within the theory can be implemented accordingly to the specific problems, both simple and complex systems. The direction of further development of this method is connected with more accurate evaluation of costs since most of them are very inaccurate at an early design stage. It is the basis for defining the technical specifications of new systems. Proposed innovation assessment method however makes it possible to compare several design concepts together and to choose the one that has a biggest potential to become profitable product on the market that is addressing needs of customers in a right way.

\section{Literature}

[1] B. Zlotin and A. Zusman, Directed Evolution: Philosophy, Theory and Practice. Ideation International Inc., 2001.

[2] K. Gadd, TRIZ for Engineers: Enabling Inventive Problem Solving. Wiley, 2011.

[3] K. Rantanen and E. Domb, Simplified TRIZ. New Problem-Solving Applications for Engineers and Manufacturing Professionals. Taylor\&Francis, 2002.

[4] G. H. Arafat, B. Goodman, and T. Arciszewski, "RAMZES: A knowledge-based system for structural concepts evaluation," Comput. Syst. Eng., vol. 4, no. 2-3, pp. 211-221, 1993.

[5] K. A. Shelton and T. Arciszewski, "Formal innovation criteria," Int. J. Comput. Appl. Technol., vol. 30, no. 1/2, p. 21, 2007.

[6] S. K. Oman, I. Y. Tumer, K. Wood, and C. Seepersad, "A comparison of creativity and innovation metrics and sample validation through in-class design projects," Res. Eng. Des., vol. 24, pp. 65-92, 2013.

[7] A. Zakrzewska- Bielawska, "Ocena innowacyjności małych i średnich przedsiębiorstw sektora ICT," in Wyzywania rozwojowe matych $i$ średnich przedsiębiorstw., Warszawa: Difin, 2011, pp. 37-53.

[8] B. Kaczmarska, "Ocena poziomu innowacyjności przedsiębiorstw na podstawie zasobów internetowych," pp. 112-123.

[9] R. Sitkowska, "Wielowymiarowa ocena potencjału innowacyjnego wytypowanych działów przetwórstwa przemysłowego," vol. 2/2011, no. 2, pp. 215-231, 2014.

[10] M. N. Saunders, C. C. Seepersad, and K. Holtta-Otto, "The Characteristics of Innovative, Mechanical Products," in ASME IDETC Design Theory and Methodology Conference, 2009, no. 512, pp. 1-38.

[11] A. Boratyńska-Sala, "Współczesny TRIZ- analiza funkcjonalna i 
trimming," in Konferencja Innowacje $w$ Zarzadzaniu $i$ Inżynierii Produkcji, 2011, pp. 26-37.

[12] S. Koziołek, "Design by Analogy: Synectics and Knowledge Acquisition Network," in Proceedings of the 13th International Scientific Conference, 2017, pp. 259-273.

[13] N. Kano, N. Seraku, F. Takahashi, and S. Tsuji, "Attractive quality and must-be quality," J. Japanese Soc. Qual. Control, vol. 14, no. 2, pp. 39-48, 1984.

[14] T. Arciszewski, Successful Education. How to Educate Creative Engineers. Successful Education LLC, 2009. 